\title{
НЕОМІФОЛОГІЧНИЙ СВІТОГЛЯД: ВПЛИВОВІ ФАКТОРИ ТА ЧИННИКИ МОДЕЛЮВАННЯ
}

У статті визначено вагому роль світоглядних підвалин у формуванні ціннісної картини світу людини того чи іншого історичного часу. Неоміфологічні світоглядні цінності можуть стати конструктивним елементом подолання кризових явищ глобалізації, повернути людину до духовних витоків та дати гідну відповідь викликам сучасної цивілізації. Автор робить висновок про те, що глибинною духовною основою культурної традиції виступає міфологічний світогляд, що розкриває архетипний зміст світовідчуття сучасної людини.

Ключові слова: міф; міфологія; неоміфологія; культура; світогляд; релігія; традиція

Постановка проблеми та стан іiі вивчення. Сучасна культурософська думка, як і гуманітаристика в цілому, знаходиться у пошуку таких сталих світоглядних орієнтирів, напрямів i концепцій, які могли би допомогти усвідомити місце людини у часі та дати надію на майбутнє подолання кризових соціокультурних явищ епохи Постмодерну. Власне, глобалізація як соціальне обличчя сучасної культури покликана виробити новітні підходи до розв'язання світоглядних проблем існування людини в світі, який набув статусу «пост».

Західноєвропейська та українська людина, переживаючи «екзистенціальний вакуум», у пошуках своєї духовності все більше відкриває шлях повернення до себе через міф. Неоміфологічний світогляд сучасної людини грунтується на відродженні міфологічної свідомості, позбавлення сцієнтизму та раціоналістичного світобачення, звернення до несвідомої сфери як необхідної умови самоусвідомлення сучасної людини.

До аналізу міфологічних витоків культури звертається західноєвропейська (Ф. Ніцше, Е. Тейлор, Ф. Шеллинг, Б. Фонтенель), російська (П. Гуревич, А. Лосев, Е. Мелетинский, М. Шахнович,), та українська (А. Білецький, Г.Булашев, Є. Бистрицький, В. Давидюк, О. Ковальский, В. Лях, М. Попович, В. Федь) філософська думка.

Мету статті обумовило те, що неоміфологічний світогляд в сучасній культурі може стати конструктивним елементом подолання кризових явищ глобалізації, повернути людину до духовних витоків та дати гідну відповідь викликам сучасної цивілізації. В таких умовах постає проблема дослідження витоків неоміфологічної свідомості, які недостатньо розробленні у вітчизняній та зарубіжній філософській літературі. Мета статті полягає у дослідженні історикофілософського аспекту витоків неоміфологічної свідомості.

Виклад основного матеріалу. Перед людством постає ряд проблем 
онтологічного значення, які обумовлюють майбутне існування культури i визначають місце людини у цій культурі. Зокрема: небезпеку виникнення термоядерної війни, забруднення біосфери планети, появу нових хвороб та епідемій, усвідомлення конечності непоновлюваних природних ресурсів, збіднення біоресурсів, демографічний вибух, голод та інші.

Кризовий стан культури обумовлює пошук нових світоглядних орієнтирів. Культура Модерну, починаючи з С. К’єркегора, Ш. Бодлера, А. Рембо, Ф. Достоєвського, та ін. тяжіла до нівелювання традиції як такої, з тенденцією до ііі повного знищення у Ф. Ніцше. Показовою у цьому плані $є$ назва роботи «Сутінки кумирів, або як філософствувати молотом», що говорить сама за себе, а з іншого боку - створювалось тло для відправної точки культуротворення - нуля, або «абсолютного теперішнього».

У Постмодерні цей пошук відбувається також за рахунок особливого ставлення до традиції. Постмодерністи (Ж. Ліотар, Ж. Бодлер, Я. Хінтікка, Ж. Дерріда та ін.) зверталися до традиції вже не з метою іiі нівелювання, але переосмислення як «прочитання» наново, що відбувається у різних формах деконструкції.

Однією 3 найважливіших змістовних форм звернення до традиції, повернення сучасності у минуле $є$ міф і міфологія як система світоглядних уявлень і узагальнень найархаїчніших часів, актуальних у сьогоденні.

Міфологічна свідомість протягом історичного розвитку культури завжди відігравала вагому роль у формуванні світоглядних цінностей людини того чи іншого історичного часу.

Вже у витоках європейської культурної традиції, починаючи від героїчного епосу античності, «Іліади» та «Одісеї» Гомера, «Прометеї закутому» Есхіла, «Електрі» Софокла, «Теогонії» («Народженні богів») Гесіода та «Бібліотеці» Аполлодора через міфологічну форму подавались базові смислоутворюючі політеїстичні світоглядні орієнтири життєво необхідні для тогочасної людини.

У давніх греків міфологічна космогонія розпочинається з образу Хаосу, який був вічним, безмежним та темним. Однак у Хаосі вже був порядок, оскільки 3 нього виникає світ та вічні боги. Також з Хаосу виникає богиня Землі-Гея та все оживляюча любов - Ерос. Саме вічний Хаос породив Морок, якого звали Ереб та Ніч - Нюкту. Від них народилося вічне Світло - Ефір та світлий День (Гемера). Отже, світло розійшлося по світу й день та ніч стали послідовно змінюватись.

Поетичність античного міфу напевно випливає з образно-символічної форми оповідання. Як відзначає А.О. Білецький, поетичне i міфологічне світосприйняття об'єднує метафора. В міфології метафора є не просто виявом образного мислення, зближення явищ за якимись їхніми ознаками, але їх ототожненням. У грецьких міфах відтворюються події сивої давнини: «відгуки ритуального людожерства (канібалізму), мотиви кровозмісних зв'язків (інцестів), розповіді про вбивства дітьми батьків і батьками дітей, братовбивчі поєдинки, 
ворожнечу родів, криваві війни племен, людські жертвопринесення, про гомосексуалізм, ритуальне скотолозтво тощо. Але всі ці прослідки епохи первісної дикості засуджуються творцями міфів, які керуються гуманною мораллю» (А.О. Білецький, 1985).

Отже, міфотворчість пориває 3 дикунством як культурним «дитинством», але не перестає відтворювати найархаїчніші сюжети.

Загалом, міфотворчість розвивається за різними «сценаріями» і напрямками освоєння дійсності. Виділяються космогонічні міфи про створення Всесвіту, теологічні міфи про походження богів, міфи про священний шлюб, солярні та астральні міфи, етимологічні міфи про походження певних явищ i речей, есхатологічні міфи про загибель Землі та людства, а також - скотарські, землеробські, героїчні та міфи про здобуття культурних здібностей.

У витоках української культурної традиції міфологія складалась переважно 3 космогонічних міфів, міфів про легендарних людей і народи, міфів про надприродних істот, небо і небесні світила, міфів про природні явища.

Окрім названих, видатний український етнограф кін. XIX - поч. XX століття, Георгій Булашев (який викладав у різних духовних і навчальних закладах, був редактором київських духовних видань) виділяє українські легенди про: створення Адама та Єви, їх гріхопадіння, вигнання, життя та смерть; походження та особливості деяких народностей; житло, господарські будівлі, знаряддя та винаходи; землю, воду вогонь і початок винокуріння; різні трави, квіти, хлібні злаки і городину; дерева і кущі; свійських тварин; риб і раків; гадів і комах (Г. Булашев, 2003).

Отже, українська міфологія має розвинену структуру, що відображає найрізноманітніші галузі взаємозв'язку праукраїнської людини з навколишнім світом і тісно пов'язана з господарсько-трудовою діяльністю людини. Вплив християнства породжує ряд легенд на біблійні міфологічні сюжети, а міфи про навколишній світ, очевидно репрезентують міфологічний шар дохристиянської язичницької духовної спадщини. Праукраїнські міфи просякнуті гумористичністю та оптимізмом.

Народна міфологія виражає найбільш характерний ментальний портрет нації. В українських міфах, на відміну від німецьких і російських за свідченням Івана Нечуя-Левицького: «Ми не бачимо в народній фантазії охоти до негарних, неестетичних велетенських міфічних образів, до тих величезних, страшних, головатих та ротатих богатирів зі страшними антинатуральними інстинктами, які любить німецька і великоруська міфологія» (В.А. Федь, 2012).

В античних міфах боги часто постають злими, розбещеними, такими, що ненавидять людину і сам Зевс ледь не знищує все людство, жорстоко карає Прометея, хоча зовнішньо боги були прекрасними.

Отже, вчинки олімпійських богів, так само як німецьких і російських були «негарними», але античні боги були антропоморфними - прекрасними і вічно 
молодими. Жахливими могли бути зооморфні істоти, - кентаври, мінотавр, гідра та інші.

Давньогрецька, еллінська, давньоримська культура на різних етапах свого розвитку реалізували формулу «від міфу до логосу». Тобто культура розвивалась від образу до поняття, від віри до розуму. Ця формула в історії людської духовності стала загальновизнаним символом зародження аргументації, логічності, послідовності доведення, загальним відображенням генезису розвитку античної людини.

Якщо за Піфагором в центрі Всесвіту знаходиться невидимий нам «вогонь», який піфагорійці називали «стражем Зевса» (тобто ще зберігається міфологічна форма), то у мілетській школі філософії (Фалес, Анаксімен, Анаксімандр) здійснюється більш рішучій відхід від міфологічних основ світобудови, що згодом реалізується у Парменіда.

Напевно якась частина людей переставала вірити у міфологічних істот $\mathrm{i}$ богів та потребувала розкриття нової картини світу, що міг дати новий світогляд побудований на раціональних засадах.

Навіть після остаточного зародження філософської парадигми, міф не втрачав своєї актуальності, через міфологічну форму осмислювались метафізичні питання, тому виникала проблема співвідношення міфологічного і раціонального у філософії.

Найбільш змістовно міф концептуалізувався у Платона, який започаткував міф про печеру, про колісницю, про андрогинів, про Атлантиду (можливо це навіть не міф, що повертає дослідника до проблеми співвідношення міфу (емоціо) і раціо (історичності) у філософіï).

Міф про печеру, як відомо, розкриває важливе положення Платона про специфіку людського пізнання. Міф про колісницю характеризує уявлення видатного мислителя про душу людини як візницю, що скеровує колісницю. Білий кінь (символіка коліру в міфі) - це благородні почуття, чорний - пристрасті людини. До речі, 3. Фройд також звертається до образу коня та вершника. Міф про андрогинів розкриває ідею архаїчної єдності чоловічого і жіночого начала. Андрогини так стали удосконалюватися, що навіть Зевс боявся їх і тому розділив на дві половинки.

Арістотель все більше відходив від міфу. Давньогрецький мислитель прагнув аргументованості логосу. Міф у «Поетиці» є лише «елементом у драмі», сюжетом твору, «складних міфів треба уникати» (Аристотель, 1998, с. 1090).

За доби еллінізму та давньоримської культури відбулось оживлення ітересу до міфу в творчості неоплатоніків, епікурейців та стоїків для яких міфологія носить пізнавальну функцію та наповнює буття понятійним змістом.

Отже, дійсно вся «антична філософія... розпочалася 3 міфу і закінчилася міфом» (А.Ф. Лосев, 37).

Хоча не тільки антична... 
Культура Київської Русі, так само як і Візантійська культура, i західноєвропейське Середньовіччя була наповнена глибоким міфологічним змістом відмінним від античного монотеїстичною системою релігійних світоглядних цінностей. Різні варіанти Середньовіччя грунтувалася на спільній світоглядній основі, яка по суті була суперечливою, а саме - літургія та карнавал (М. Бахтін).

Середньовіччя утворило суттєво нову, відмінну від античної, міфологічну основу, яка органічно синтезувала світоглядні начала літургії та карнавалу. Головним чином відбулася міфологізація релігійної свідомості, яка, власне, не мислилась тоді і понині без міфу. При цьому релігія, на відміну від міфу, встановлювала трансцендентальний зв'язок людини з Богом через культ.

Відмінність вітчизняного варіанту православ'я полягала у міфологізації не тільки народної, язичницької у своїй основі, культури скільки культури релігійної. Якщо у Західній Європі та Візантії інститут церкви «подолав» язичницький міф, в якійсь мірі замінивши його біблійною історією, то у Київській Русі існувала синкретична єдність язичницької та християнської міфології реалізована у двовір'ї.

Якщо у католицизмі та навіть візантійській церкві язичницькі міфологічні елементи існували у народній карнавальній культурі, то на вітчизняному грунті вони були присутні та навіть в чомусь були визначальними у релігійній площині.

За часів Відродження відбувалось повернення до античної спадщини далеко не в останню чергу міфологічної за своєю природою та сутністю. Зокрема, художня спадщина Боттічеллі, Рафаеля, Мікеланджело грунтувалась на античній міфології, була пронизана тонкою поетичністю та вишуканістю художнього стиля.

Висновки. Таким чином, витоки неоміфологічного світогляду характеризують сутнісні онтологічні механізми взаємодії як архаїчної так само і сучасної людини зі світом та розкриває сутнісний зміст історичних і сучасних культурних практик. Глибинною духовною основою культурної традиції виступає міфологічний світогляд, що розкриває архетипний зміст світовідчуття сучасної людини.

\section{СПИСОК ВИКОРИСТАНИХ ДЖЕРЕЛ}

Аристотель Поэтика. Об искусстве поэзии // Аристотель. Этика. Политика. Риторика. Поэтика. Категории. Минск: Литература, 1998. - С. 1064-1112/

Білецький А.О. Міфологія і міфи Античного світу // А.О. Білецький / Словник античної міфології. - Київ, 1985 - 236 с. Електронний ресурс: http://litopys.org.ua/slovmith/slovm02.htm

Лосев А.Ф. История античной философии в конспективном изложении // А.Ф. Лосев. М.: «ЧеРо», 1998. - 187 c.

Міфи України // Булашев Г. Український народ у своїх легендах, релігійних поглядах та віруваннях / Г. Булашев; пер. Ю. Буряка. - К. : Довіра, 2003. — 383 с. 
Нечуй-Левицький I. С. Світогляд українського народу. Ескіз української міфології / I. С. Нечуй-Левицький. - К.: Обереги, 1992. - 88 с.

Федь В.А. Міфологічна парадигма у витоках української культури / В.А. Федь // Схід. Донецьк, 2012. - № 3 (117) травень-червень. - С. 146-149.

МАРИАННА ШАРНИНА старший преподаватель кафедры культурологии, естетики и истории Донбасский государственный педагогический университет (2. Славянск, Украина) email:mariannasharnina26@gmail.com ORCID ID 0000-0001-7969-4751

\section{НЕОМИФОЛОГИЧЕСКОЕ МИРОВОЗЗРЕНИЕ: ВЛИЯТЕЛЬНЫЕ ФАКТОРЫ МОДЕЛИРОВАНИЯ}

В статье определена важная роль мировоззренческих устоев в формировании ценностной картины мира человека того или иного исторического времени. Неомифологические мировоззренческие ценности могут стать конструктивным элементом преодоления кризисных явлений глобализации, вернуть человека к духовным истокам и дать достойный ответ вызовам современной цивилизации. Автор делает вывод о том, что глубинной духовной основой культурной традиции выступает мифологическое мировоззрение, которое раскрывает архетипический смысл мироощущения современного человека.

Ключевые слова: миф; мифология; неомифология; культура; мировоззрение; религия; традиция

MARIANNA SHARNINA senior Lecturer of the Culturology, Aesthetics and History Chair Donbass State Pedagogical University email:mariannasharnina26@gmail.com ORCID ID 0000-0001-7969-4751

\section{NEOMYTHOLOGICAL WORLDVIEW INFLUENTIAL MODELING FACTORS}

The article defines a significant role in shaping the philosophical foundations of the value of world picture for a person on the current stage of historical development of the global world. Neomythological ideological values can be a constructive element in overcoming the crisis of globalization, they can help a man to return to his spiritual roots and give an adequate responses to the challenges of modern civilization. The critical state of culture makes a man to look for the new ideological orientations. Consequently, investigation, understanding of mythological and neomythological explanation of the world becomes acute and actual scientific problem. Analysis of publications reflects that mythological foundations of different cultural models were investigated in numerous scientific works, but neomythological process in the modern Ukrainian society revealed fragmentary. The results of the article reflect that in the Postmodern period searching of new spirit values and axiological moduses is released due returning to a tradition. The author concludes that the deep spiritual foundation of cultural tradition stands for the mythological world outlook that reveals the archetypal content of the attitude of a modern man to his time. One of the most meaningful form 
of appealing to tradition, to the past is a myth and mythology as a system of philosophical concepts and generalizations of the most archaic stereotypes, ancient times of cultural development. New, neomythological outlook is based on the revival of mythological consciousness, appealing to the unconscious sphere, as a necessary condition of self-consciousness of a modern man, who is in search of his spirituality more often opens path back to himself through a myth. Ukrainian myths, unlike German and Russian ones, are imbued with humour and optimism, and folk mythology expresses the most typical mental picture of the nation. As the result of the study the author has concluded that myths are an integrated part of the national worldview, world-perception, and world-understanding. Every cultural model permanently creates myths as an instrument of cognition and understanding of surrounding, as a mean of existence sense-making. And new postmodern era isn't exception. Neomythological processes in the modern Ukrainian society are based on humour and optimism as meaningful, influential features of the national worldview.

Keywords: myth; mythology; neomythological; culture; philosophy; religion; tradition

\section{REFERENCES}

Aristotel' (1998) Poetika. Ob iskusstve poezii. Etika. Politika. Ritorika. Poetika. Kategorii. Minsk: Literatura. P. 1064-1112 (In Russian)

Biletskyi A.O. (1985) Mifolohiia i mify Antychnoho svitu. Slovnyk antychnoi mifolohii. Kyiv, 1985. Rettieved from http://litopys.org.ua/slovmith/slovm02.htm (In Ukrainian)

Losev A. F. (1998) Istoriya antichnoj filosofii v konspektivnom izlozhenii. M.: «CHeRo». (In Russian) Bulashev H. (2003) Mify Ukrainy. Ukrainskyi narod u svoikh lehendakh, relihiinykh pohliadakh ta viruvanniakh. K.: Dovira. (In Ukrainian)

Nechui-Levytskyi I. S. (1992) Svitohliad ukrainskoho narodu. Eskiz ukrainskoi mifolohii. K. Oberehy. (In Ukrainian)

Fed V.A. (2012) Mifolohichna paradyhma u vytokakh ukrainskoi kultury. Skhid. Donetsk, № 3 (117). P. 146-149. (In Ukrainian)

\section{Надійшла до редакції 13.11.2019 р.}

